\title{
Law and Gospel Order: resolving commercial disputes in colonial Philadelphia
}

\author{
Esther Sahle* \\ University of Oldenburg \\ *Corresponding author. Email: esther.sahle@uni-oldenburg.de
}

\begin{abstract}
Trade in the early modern Atlantic grew a great deal. While acknowledging that this growth had important economic, social and cultural consequences, scholars have yet to fully explain its causes. This paper argues that formal religious institutions were key. Based on records from colonial Philadelphia, it shows how the Quaker meeting created a legal forum to resolve commercial disputes. The meeting enforced its verdicts by gathering and disseminating information about disputes locally and across the Atlantic world through the Society of Friends' formal organisation of meetings. Thereby, it re-enforced reputation mechanisms, facilitating the expansion of Philadelphia's trade.
\end{abstract}

In pre-modern societies, long-distance trade constituted a key motor for economic growth. The expansion of trade in the British Atlantic facilitated social mobility and the emergence of the middling sorts as an economic and political force in England. Some prominent scholars have argued that it laid the foundations for the Industrial Revolution, making it the root of present-day global inequality. ${ }^{1}$ The factors determining trade expansion, however, remain unclear. Economic historians researching trade have been strongly influenced by the New Institutional Economists (NIE). ${ }^{2}$ These argue that within Europe, the emergence of strong, centralised states who enforced property rights enabled trade. European states were however unable to extend their control to the American colonies. The growth of trade in the Atlantic despite weak state structures poses a puzzle yet to be solved.

This article offers a solution to this puzzle. Based on the extensive records of colonial Philadelphia's Quaker Monthly Meeting, it shows that in the face of weak state institutions, formal religious institutions evolved to enforce property rights. Its argument is threefold. First, the Meeting established its own legal forum, where it solved commercial disputes through arbitration. Second, it did this in order to compensate for the unreliable public courts. Third, it ensured that litigants honoured its decisions by means of a formally reinforced reputation mechanism. The importance of reputation mechanisms in early modern trade is well established. The Quaker Monthly Meeting is distinct as it found a way to employ reputation mechanisms formally, thereby increasing their impact. It

\footnotetext{
(C) The Author(s), 2020. Published by Cambridge University Press. This is an Open Access article, distributed under the terms of the Creative Commons Attribution licence (http://creativecommons.org/licenses/by/4.0/), which permits unrestricted re-use, distribution, and reproduction in any medium, provided the original work is properly cited.
} 
gathered, verified and published information about conflict parties and its own verdicts through the formal institutions of the Society of Friends. Thereby, it made sure that the information it had was reliable. Through its formal institutions, the Society was able to spread this information more widely and with greater credibility, thereby achieving greater impact than reputation mechanisms based on informal networks. This worked while Philadelphia's population remained small and relatively homogenous. When immigration increased and the city's society grew more diverse, the reinforced reputation mechanism lost its power and merchants stopped using Philadelphia Monthly Meeting for dispute resolution.

The article further explains that the reason scholars have paid little attention to the role of formal religious institutions in trade lies in the lack of communication between historical disciplines. Economic historians researching trade have ignored research by legal historians. These have established that the early modern world was legally pluralistic, bodies other than the state providing and enforcing law the norm. Combining these two disciplines' findings reveals an explanation for the expansion of trade in the early modern Atlantic. The findings, moreover, hold implications for the roots of pre-modern trade expansion globally.

The article is divided into nine sections. Section 1 reviews the scholarship on premodern long-distance trade and sets out the problem of explaining Atlantic trade expansion. Section 2 discusses the scholarship on pre-modern legal institutions and governance. It shows that by relying too strongly on the New Institutional Economics, trade historians have missed legal historians' findings on the legal pluralism of pre-modern societies. Section 3 sets out the current state of knowledge on Quaker dispute resolution. Section 4 outlines the legal, political and economic situation of early colonial Pennsylvania. Section 5 provides an empirical study of the number and types of disputes Philadelphia Monthly Meeting solved. Section 6 shows that a high percentage of conflict parties in the Meeting were merchants. Section 7 conducts a comparison between Philadelphia and London Monthly Meetings and reveals that dispute resolution was not an inherent part of Quaker discipline, but particular to the colonial context. Section 8 outlines how Philadelphia Monthly Meeting enforced its verdicts, using a special mechanism based on both formal structures and reputation. Section 9 sums up the findings and discusses their implications for our understanding of pre-modern trade expansion in general, and trade in the Atlantic in particular.

\section{The fundamental problem of exchange}

The key element inhibiting trade expansion is risk. Long-distance trade is marked by a time lag between delivery of goods and payment. Merchants in locations that are far apart agree to exchange payment and goods. They accept the risk that the other party will not deliver as promised. Such a breach of contract may cause financial ruin. Thus, this risk needs to be mitigated for trade to occur. The smaller the risk, the more individuals will be willing to enter the market, the more trade and exchange will take place, and the more economic growth occurs. In consequence, prosperity may increase and living standards improve. A growing body of opinion sees institutions as the solution to this problem. Depending on the quality of institutions for contract enforcement, trade will grow - or not - in a given time and place. This implies that trade increases reflect institutional improvement. 
According to the NIE, in early modern Europe the state emerged as the main guarantor of property rights. ${ }^{3}$ Beginning in the late Middle Ages, European countries moved from a situation in which private order institutions dominated contract enforcement towards one in which the state played an ever greater role. Public courts, relying on the state's monopoly of force to carry out their verdicts, came to replace earlier, private institutions. The English state proved particularly successful in monopolising contract enforcement. Over the course of the early modern period, it developed an increasingly centralised judicial system, which dealt out justice throughout the state's territory. ${ }^{4}$ According to Douglass North and Robert Thomas, the Glorious Revolution of 1688 was a watershed in this development. It enabled the central government to consolidate control and complete the centralisation of the judicial system. This was important, as North and Thomas argue, because it allowed public courts to enforce contracts throughout the state's territory. ${ }^{5}$ Similar developments took place, albeit to a less complete degree, throughout Europe. This meant that merchants in Europe could resort to courts when business associates broke their promises to pay debts or deliver wares. The courts heard the dispute, found one party guilty and ordered them to pay. The state then enforced its courts' verdicts. Thereby it facilitated trade expansion and sustained economic growth. ${ }^{6}$

In areas where courts were either unavailable or inefficient, merchants had to rely on private or community-based institutions to enforce contracts. Avner Greif famously theorised that in the medieval Mediterranean, the Maghrebi merchants used multilateral reputation mechanisms to enforce contracts. Any merchant who broke a promise was ostracised and lost the prospect of future trade with any member of the community. However, membership in pre-modern merchant communities was based on faith, kinship or other pre-existing, non-economic, criteria. This limited the number of those who could use the reputation mechanism, and thereby the number of people who would participate in the market. These private order institutions were, therefore, less capable of supporting trade than public courts, setting limits to market expansion and economic growth.

While Greif maintained that merchants accessed either public or private order institutions, and that these emerged sequentially, with public order institutions replacing private order ones, researchers including Jessica Goldberg, Regina Grafe and Oscar Gelderblom have since shown that pre-modern merchants used both state and private order institutions in tandem, making use of any tool available to reduce risk. ${ }^{7}$ In the colonial trades, these included multilateral reputation mechanisms based on kinship, local origin and faith. ${ }^{8}$ Merchants used courts, but only as a last resort. As Philadelphia merchant Isaac Norris informed a correspondent about his attempts to secure a debt, 'I have been very pressing with Jos. Jones, and do all in my power, but don't love the law'. ${ }^{9}$ Early modern merchants across the Western hemisphere shared in this sentiment. ${ }^{10}$ Courts were expensive and slow; they could harm one's reputation and were thus best avoided.

Legal historians agree that whenever possible, traders resorted to arbitration instead. ${ }^{11}$ This was particularly true for American merchants, who were faced with unreliable public courts. Their preference for arbitration continued until the mid-eighteenth century, when courts improved and litigation became prevalent. ${ }^{12}$ For arbitration to be able to solve disputes and enforce contracts, arbitration awards need to be enforced. Yet it is unclear how American colonists accomplished this. 
Bonds are one contender. ${ }^{13} \mathrm{~A}$ bond obliged parties to a contract to pay a fine if they did not fulfil their side of the agreement. However, enforcing bonds required going to court, which limited their use. Given these institutional constraints, how do we explain the sustained expansion of trade that took place in the Atlantic during the late seventeenth and early eighteenth century?

Scholarship on Atlantic trade has overlooked an important piece of the institutional puzzle: the state was not the only provider of 'law' in the colonies. In the absence of a strong state, multiple alternatives can offer institutional solutions. These may include private corporations, such as the chartered trading companies, or religious bodies like the Anglican church. In Pennsylvania, religion was the most important of these. Religion's role as the basis for informal trading networks in the Atlantic is long established. This paper argues that religion did more than that. In Pennsylvania, the Society of Friends stepped in to fill the institutional vacuum left by weak state institutions: It established legal forums. These were formal institutions in that they followed standardised procedures based on written rules. As part of the institutional landscape of colonial Pennsylvania, they enforced contracts and thereby facilitated trade expansion.

\section{Important lessons from Legal History have been overlooked}

Why has the possibility of formal religious institutions enforcing contracts in the colonies been neglected? Studies on the institutional foundations of long-distance trade have been influenced strongly by the NIE view of the state. This is based on the concept of 'legal centralism'. 'Legal centralism' assumes that 'law' only exists within and through the power of the nation state and that the nation state is in control of everything happening in its territory. ${ }^{14}$ At the time of North's first writing on the state's role for protecting property rights in 1973, legal centralism was the generally accepted understanding of how law works. However, legal scholarship has since moved on from this view. Over the course of the 1970s and 1980s, legal historians replaced the idea of 'legal centralism' with that of 'legal pluralism'. ${ }^{15}$ There are two models of legal pluralism: 'Weak' legal pluralism posits that there are several legal orders in one territory, which ultimately derive their legitimacy from the state. 'Strong' legal pluralism frees law from its ties to the nation state. Instead, it posits that legal orders are connected to 'semi-autonomous social fields'. A semiautonomous social field is a 'social group which engages in reglementary activities'. ${ }^{16}$ It is not defined by its boundaries, but by 'the fact that it can generate rules and coerce or induce compliance to them. ${ }^{17}$ At the same time, it is part of, and influenced by, a larger society. ${ }^{18}$ Social fields overlap. Ergo, several legal orders will operate within the same social and economic space. ${ }^{19}$ This means that within a state's territory, forces other than the state will provide and enforce law. The more socially diverse a society - its members organised along ethnic, socio-economic, religious and occupational lines - the more pluralistic the legal order in that society will be. ${ }^{20}$

Contrary to North et al.'s theory, in early modern Europe, the state did not enjoy a monopoly of force. While it was making efforts towards greater judicial control, progress remained slow. The institutions European states created to address commercial disputes were hybrid, that is, they combined state and private elements. English bankruptcy commissions consisted of merchants who, while appointed 
by the Lord Chancellor, investigated commercial failures and determined debtors' obligations and creditors' rights independently. ${ }^{21}$ English colonies in North Africa and the Caribbean setup merchant courts, where instead of judges with legal training, merchants themselves decided commercial disputes. ${ }^{22}$ At the King's Bench in London, Lord Mansfield relied on merchant juries in order to comprehend and decide commercial cases. ${ }^{23}$ Sixteenth-century France created courts staffed by merchants rather than professional judges, who used their expertise to solve commercial disputes. Courts of this nature exist in France to this day, so legal centralism is still not a reality. ${ }^{24}$

England remained legally pluralistic throughout the early modern period. Philip Loft recently showed that even after 1688, local corporations and power holders heavily curtailed parliament's influence. ${ }^{25}$ The 'state' constituted one corporation among many, all of which governed by sharing power and cooperating with each other to various degrees. ${ }^{26}$ Royal, local, ecclesiastical, and seigniorial jurisdictions, provincial and local estates, feudal lords, guilds, urban corporations and trading companies all provided and enforced law. Many of these legal institutions did not derive their legitimacy from the crown. ${ }^{27}$ In Philip Stern's words, the early modern European 'state' was really a 'composite of agents, networks, and "grids of power" that operated within, aside, and sometimes in conflict with the sovereign Crown'. Correspondingly, Larry Epstein argued that the NIE 'project backwards in time a form of centralised sovereignty and jurisdictional integration that was first achieved ( ... ) during the nineteenth century; they therefore fundamentally misrepresent the character of pre-modern states' ${ }^{28}$ These were unable 'to enforce $(\ldots)$ a unified legal regime. ${ }^{29}$

The acquisition of overseas territories further increased legal plurality. In the colonies, new situations and conflicts arose which European law lacked the instruments to resolve. ${ }^{30}$ Lauren Benton has shown how European empires responded to this challenge by adopting and incorporating local legal orders. ${ }^{31}$ This understanding of the plurality of law has not yet been applied in research on the institutional foundations of long-distance trade, despite the recognised importance of semiautonomous structures, such as the English and Dutch East India Companies in this context. As Philip Stern and Adam Clulow have shown, these corporations, crucial to the expansion of long-distance trade, enjoyed sovereignty and jurisdiction over their 'subjects', making and enforcing law that governed trade. ${ }^{32}$

\section{Quaker dispute resolution}

One such non-state legal institution supported trade expansion in the Atlantic: the Philadelphia Quaker Monthly Meeting (PMM). Founded in 1682, Philadelphia suffered from a fragile institutional environment. The political situation was instable and the legal structure malfunctioning. These factors conspired to make Philadelphia an unlikely candidate for commercial success. Yet, the city's commerce thrived. How was this possible? This paper argues that Philadelphia Monthly Meeting played an important role in this development.

The Quaker Monthly Meeting was a religious private order institution. In colonial Pennsylvania, there were some overlaps between Quaker meetings and the state - some of PMM's officers also acted as judges or magistrates. Formally, however, 
the two were distinct, and the meeting was independent of the state. The Society of Friends' arbitration procedure was based on scripture and followed the same pattern commonly used by English guilds to solve disputes between members. ${ }^{33}$ Arbitration in a Quaker Monthly Meeting was open to Friends only. Friends were first to try and solve their differences privately. If unable to reach an agreement, the aggrieved party was to recruit some 'judicious and discreet Friends' to negotiate with the opponent. If their efforts failed, too, the parties were to 'choose referees, or arbitrators', and promise to honour their verdict. Only if an opponent refused to take this step, should Friends approach a monthly meeting for help. At the monthly meeting, the parties each chose several arbitrators who together would make inquiries, uncover evidence and discuss the conflict. The monthly meeting would 'add one or more friends to them ( ... for determining the said difference by a majority. ${ }^{34}$ The arbitrators were to determine the case swiftly and report to the next monthly meeting. Appeals could be directed to a quarterly meeting and eventually a yearly meeting. ${ }^{35}$

We know that Friends arbitrated disputes in their meetings. Morton Horwitz argued that a Quaker preference for arbitration led to an unusually frequent use of that form of dispute resolution in Pennsylvania. ${ }^{36}$ Carli Conklin's study of arbitration in colonial Quaker records has established that Friends in the Jerseys also used arbitration, as well as the rules by which this procedure took place. ${ }^{37}$ Peter Philips argued that arbitration in Quaker meetings was common in the seventeenth century and gradually declined from the nineteenth century onwards. His study is based on several editions of the Society of Friends' Discipline, using a few examples of disputes arbitrated by various American Quaker meetings for illustration. The Discipline, however, is not evidence of actual Quaker practice. It sets out how Yearly Meetings would have liked Friends to behave, while containing no information on what actually took place at the monthly meeting level. ${ }^{38}$ None of these studies provide evidence of the frequency of arbitration in Quaker meetings, how it developed over time, who was involved and what types of conflicts were arbitrated. A quantitative study of arbitration in rural Pennsylvania Quaker meetings by William Offutt conflates dispute resolution with the meetings' regular disciplinary procedures. In the latter, rather than responding to a member's complaint against another, monthly meetings became active on their own behalf to deal with members who broke the Quaker discipline, and whose behaviour threatened to cause the Society reputational harm. ${ }^{39}$ This is distinct from dispute resolution, in which individual Friends approached the meeting with cases of disagreements with each other. As a consequence, the image that emerges from Offutt's study is distorted, overestimating the use of dispute resolution. To sum up: We know that Quaker dispute arbitration took place in Pennsylvania, and we know the formal rules the Society laid out for the procedure. So far, we do not know how common the procedure was, who used it, and what types of disputes they brought to the meetings.

\section{The Quaker colony and its courts}

The Quakers are a dissenting group that emerged during the English Civil Wars in the 1640s. Their core belief was the immediate relationship between the individual and God, without the need for priests to serve as intermediaries. ${ }^{40}$ They emphasised 
the importance of personal religious experience over the knowledge of scripture. The participation of those 'convinced' was central. At meetings, Friends might sit completely silent for hours, each listening for the voice of God within. ${ }^{41}$ The early Quakers missionized very successfully, and by 1700 , there were about 50,000 Quakers worshiping in meetings all over the British Empire. ${ }^{42}$ A formal, hierarchically structured organisation connected their meetings. At its lowest tier stood local meetings for worship, where Friends gathered several times a week. At the next higher level stood the monthly meetings. They consisted of respected community members, often merchants or other, wealthier Friends. The monthly meetings were responsible for the administration of the communities in their areas. They organised poor relief, registered births, solemnised marriages, maintained Friends' buildings and burial grounds. In this, they shadowed the Anglican parish. Quaker Monthly Meetings, furthermore, sanctioned Friends whose behaviour might cause the community's reputation to suffer, such as public drunkenness. Monthly meetings also kept up a regular correspondence with other Quaker meetings. ${ }^{43}$ They sent emissaries to quarterly meetings, which in turn dispatched representatives to yearly meetings. Yearly meetings were the highest body within the Quaker organisation, possessing the greatest authority. The most important yearly meetings were located in London and Philadelphia. They formulated Quaker policies regarding all issues that concerned Friends or the public at large, from how to raise one's children to participation in privateering. They issued annual letters, called epistles, which form the basis of the Quaker discipline. They also decided internal conflicts. Their decisions were binding for all lower-tier meetings.

Until 1660, Quakers tried to bring about a radical reform of society. Emphasising equality before God, Friends rejected the authority of the Anglican Church and to a certain degree that of the state. The government responded to their dissent from social and political order with persecution. It banned Quaker meetings and expropriated Friends' possessions. Thousands were incarcerated, hundreds died in prison. ${ }^{44}$ Only with the Toleration Act of 1689 did persecution decrease and Friends gain some security. ${ }^{45}$ In response to persecution, in 1681, William Penn obtained a charter from Charles II to found Pennsylvania as a place where Friends could live safely in accordance with their beliefs.

Settlement of the colony began in 1682. Historians agree that it was an immediate success. ${ }^{46}$ Within three years of the first ships' arrival, Philadelphia 'was firmly established in the Barbados provisioning trade and had cut deep inroads into New York's control of the middle-Atlantic fur and tobacco markets' ${ }^{47}$ Gary Nash concluded that 'There are few parallels in colonial history to the economic success of Pennsylvania in the first two decades' ${ }^{48}$ Philadelphia exported tobacco, skins, furs, lumber and flour to the West Indies. In return, its merchants received bills of exchange. These were used to purchase English manufactured goods via the New England colonies. This pattern lasted almost 40 years. Around 1720, a major change occurred: More wheat and flour were sold to Southern Europe and Ireland, and the coastal trade with the other colonies grew, too. In the following years, Philadelphia's external trade almost tripled. ${ }^{49}$

Demographic developments mirrored these economic ones. In 1690, Philadelphia counted roughly 2,000 inhabitants, including 1,100 Quakers. ${ }^{50}$ The 
city's population stagnated until 1718 . Then, immigration increased. In 1720 , just below 5,000 inhabitants lived in Philadelphia. By 1775, their number had grown to $32,000 .^{51}$ The new arrivals were pre-dominantly non-Quaker, many stemmed from continental Europe. ${ }^{52}$ It is unclear when Friends became outnumbered by others. PMM's 1760 census lists 2,250 Quaker women, men and children. ${ }^{53}$

Until about 1720, the colony suffered from political and legal instability. ${ }^{54}$ The frame of government changed repeatedly. ${ }^{55}$ The colonial assembly frequently passed laws, only to have them repealed by the crown. Offutt found that Pennsylvania suffered 'the highest percentage of disallowed colonial legislation'. ${ }^{56}$ For instance, in 1706, the Privy Council revoked 53 of 105 laws submitted by the assembly. ${ }^{57}$ In between sending laws for approval to England and hearing back about their acceptance, rumours and uncertainty ruled. This led to general confusion over which laws were in place, as well as colonial courts' jurisdiction. ${ }^{58}$

Pennsylvania had four types of courts: The county courts sat four times a year, alternatively as courts of quarter sessions and common pleas. The quarter sessions heard non-capital criminal cases, while courts of common pleas handled civil disputes. In addition, there was an orphan court, which administered decedents' estates and appointed guardians for their children. The lines between these courts were permeable, as the same judges presided in all four, deciding cases in common pleas, sessions, equity and orphan courts. ${ }^{59}$ Finally, a 'Provincial Court', which travelled from county to county in circuit, heard the most serious criminal cases as well as appeals from civil and equity cases.

Of special importance to our study is equity jurisdiction. This was controversial, and nowhere more so than in the Quaker colony. ${ }^{60}$ According to Stanley Katz, 'Controversies over the nature of jurisdiction of equity courts was a distinguishing feature of early Pennsylvania political life. ${ }^{61}$ Proponents of equity courts argued that these were essential to economic development, as they remedied short-comings of common law which made it difficult to obtain justice in commercial cases. Proceedings in common law were bound by a stiff framework. Pleadings had to fall within established writs - or formulars - to allow for litigation. This considerably narrowed the types of grievances plaintiffs were able to bring to court. Common law pleadings, furthermore, had to be framed in a way that 'narrowed the dispute to a single question of law raised against a single defendant', in order to make them easier for juries to understand and decide. Moreover, common law did not permit the parties themselves to appear as witnesses, thereby disqualifying important evidence. ${ }^{62}$ In equity courts, in contrast, plaintiffs were able to file cases against multiple parties, and others involved in the suit were able to add their own related claims. Equity courts relied on testimonies in writing, including that of the dispute parties, and generally included a broader range of evidence. This, as Amalia Kessler put it, increased 'the probability that the suit would be decided in accordance with the actual facts'. ${ }^{63}$

Some colonists worried because equity courts acted without juries, while at the same time being headed by the governor. They feared such courts would give too much power to proprietors, while disadvantaging the colonists. For instance, it might force them to pay quitrents. ${ }^{64}$ These concerns existed across the American colonies. Different provinces found different solutions for the dilemma. New York, Maryland and South Carolina did introduce chancery courts, which 
were active for long periods of time. ${ }^{65}$ Most of the New England colonies incorporated equity law and procedure into common law legislation and courts. In Massachusetts, home to the highly successful port of Boston, county courts were empowered to 'act as courts of equity, and they retained this authorization throughout the colonial period'. ${ }^{66}$ Pennsylvania experimented in this direction. Equity powers of common law courts were introduced or confirmed repeatedly between 1684 and 1720. However, the Queen repealed them each time. This meant that in the period between the assembly passing the legislation granting equity powers to the county courts, and news of the repeal reaching Pennsylvania, the county courts did hold these powers. They lost them the moment the repeal became known. Courts with equity powers were active in Pennsylvania briefly after 1684, again from 1690 to 1693 , from 1701 to 1705 , from 1710 to 1713 and 1715 to $1719 .^{67}$ This back and forth led to constant confusion over whether the courts held equity powers or not. ${ }^{6}$ Importantly, it also caused insecurity as to whether verdicts issued by equity courts in these periods would hold and be enforced once the courts lost their equity powers again. Only in 1720 would the colony finally establish a durable equity court, which operated until $1736 .^{69}$ After the final abandonment of this court, common law courts slowly began to adopt individual equity procedures. $^{70}$

The insecurity regarding Pennsylvania's courts was further aggravated by the 'oath controversy' from the 1690 s to about $1720 .^{71}$ The English legal system required the swearing of oaths throughout. As part of their beliefs, Friends refused to swear. In Pennsylvania, they therefore replaced oaths with affirmations. However, Pennsylvania colonists from the outset included other protestants as well. Soon, a power struggle between Friends and non-Quaker settlers emerged, centring around the use of oaths. Anglicans argued that the lack of oaths made the justice system unfit to deal with crime, lobbying for a replacement of affirmations by oaths locally and with the government in England. Losing the option of affirming would have put Quakers at a serious disadvantage in the legal system, making it impossible for them to litigate, and excluding them from acting as judges or jurors. Moreover, it raised the question whether courts' decisions based on the use of affirmations would continue to be binding, if these became outlawed. Churchmen brought the legal process to a halt repeatedly. ${ }^{72}$ Between 1705 and 1710, Pennsylvania's courts functioned merely based on ordinances issued by the governors. During brief periods in 1708 and 1709, they did not sit at all. ${ }^{73}$

Political instability further eroded trust in the courts. William Penn was twice arrested after the Glorious Revolution under charges of treason, due to his close relationship with former King James II. Between 1692 and 1694, the colony came under crown control, as it failed to take measures to defend itself against the French in the War of the League of Augsburg. ${ }^{74}$ In 1708, Penn again was imprisoned, this time for debts. Close to bankruptcy, he prepared to sell the colony to the crown. These plans hung over Pennsylvania until his death in 1718. Penn's heirs held on to the colony and appointed governors to represent their interests vis-à-vis the Pennsylvania Assembly. The legal and political situation improved dramatically from about 1722 onwards. $^{75}$ Political unrest calmed down, laws remained in place and courts sat regularly.

Given the constraints described above, how did Philadelphia Quaker merchants solve commercial disputes and enforce contracts? The inhabitants of 
early modern European states and empires, including merchants, compared the services and possible outcomes they could expect from dispute resolution in different legal forums, choosing the one they thought would provide for them most desirable outcome. ${ }^{76}$ The seventeenth- and early eighteenth-century records of Delaware Valley courts outside Philadelphia show that in spite of their unreliability, Friends at times did apply to the courts for help. ${ }^{77}$ Moreover, their letters show that they often used informal arbitration, which was common practice in both the colonies and England. ${ }^{78}$ In addition, as the following sections of this paper will show, Friends obtained help from the Quaker Monthly Meeting to solve disputes.

\section{The Quaker meeting offers an alternative to public courts}

Philadelphia Yearly Meeting's 1719 Book of Discipline first defined the types of conflicts that might be brought to monthly meetings' attention. These included 'differences (that) happen or arise between any Friends' in 'their interests, claims or properties in worldly affairs'. ${ }^{79}$ It specified debts, bonds and 'differences in accounts. ${ }^{80}$ This tells us first, that the Yearly Meeting intended the arbitration process not for spiritual or religious matters, but for conflicts of a secular nature. Specifically, it had in mind differences that arose during the conduct of business - conflicts likely to involve contracts. To what extent did PMM employ this procedure? What types of conflicts did it focus on in practice? Its minutes provide answers to these questions. They survive for the entire colonial period. In 1772, PMM split in three to accommodate the growing size of the city and community. For the sake of simplicity, this study uses only the records of the original monthly meeting and ends in 1772 (Table 1).

The minutes specify the causes of conflicts for 161 cases (56.1 per cent). The remainder concerns undefined 'differences' or 'complaints'. Which causes were specified appears determined by chance. The known causes were divided into categories according to issues which appeared most frequently. The largest category is 'debt', constituting 57.5 per cent of causes. In 1744, for example, George James complained that Samuel Redman was 'indebted to him and delays payment'. ${ }^{81}$ PMM appointed two Friends to 'use their endeavours to get the matter accommodated' ${ }^{82}$ The following month, these reported that Redman 'promiseth to pay the money in a few days'. ${ }^{83}$ In response, PMM directed the two Friends to follow up on the case, to ensure he kept his promise. Again, the following month, they reported to the meeting that the procedure continued, and the next, the minutes noted that it was 'ended'. ${ }^{84}$

The next largest group is 'estates', with 21.9 per cent. This includes cases in which creditors complained against the executers of deceased persons' estates. The vast majority of these concern the settlement of debts owed by, or to, the deceased. Therefore, both 'debts' and 'estates' constitute conflicts over the payment of debts. Together, conflicts over financial obligations make up at least 79.4 per cent of cases PMM arbitrated.

A closer look at the debt cases reveals that they often concerned commerce, some explicitly long-distance trade. They include conflicts over bills of exchange, differences in accounts and money lent on bond. ${ }^{85}$ The minutes often do not specify 
Table 1. Conflicts arbitrated by Philadelphia Monthly Meeting

\begin{tabular}{llll}
\hline & Causes & Per cent/ Total & Per cent/ Known cases \\
\hline Unknown cause & 127 & 44.3 & - \\
\hline Debt & 92 & 32.1 & 57.5 \\
\hline Estates & 35 & 12.2 & 21.9 \\
\hline Land & 10 & 3.5 & 6.3 \\
\hline Law & 10 & 3.5 & 6.3 \\
\hline Other & 4 & 1.4 & 2.5 \\
\hline Defamation & 3 & 1.0 & 1.9 \\
\hline Abuse (physical/verbal) & 3 & 1.0 & 1.9 \\
\hline Business other & 3 & 1.0 & 1.9 \\
\hline Total & 287 & 100 & - \\
\hline Known cases only & 160 & 55.7 & 100.0 \\
\hline
\end{tabular}

Source: Haverford Special Collections, Philadelphia Monthly Meeting Minutes.

whether the conflict was between Friends residing in Philadelphia, or elsewhere. While PMM arbitrated his complaint, Francis Richardson was actually living in New York. This is not obvious from the minutes, however, and is only revealed by his correspondence. ${ }^{86}$ Other Friends in PMM may have acted as agents for their overseas correspondents, without this being specified in the minutes. Fifteen cases (16.3 per cent) can with certainty be identified as involving at least one party living in a different colony or in England. ${ }^{87}$ These Friends were represented at PMM by their agents, or their home meetings approached PMM by letter.

For instance, in 1687, Daniel Wharley, Quaker and hatter of London needed help with a bill of exchange he received from Philadelphia Quaker merchant Griffith Jones. Instead of taking the case to court, Wharley asked his correspondent, Samuel Carpenter, merchant of Philadelphia, for support. Carpenter approached Jones but could not convince him to compensate Wharley for the protested bill. As a next step, Carpenter turned to PMM. He reported Jones 'for not satisfying this Bill of Exchange to him in the behalf of Daniel Wharley with charge of protest and interests since it became due'. He requested PMM exert pressure on Jones. PMM directed that:

Griffith Jones shall pay unto Samuel Carpenter on the behalf of Daniel Whaley the money due upon the aforesaid bill of exchange protested, with the lawful damage and protest, and also the full interest of six $\mathrm{p}$ cent since the first day the bill arrived in Pennsylvania after it came back protested from England, and to pay the same in silver money or to content of the said Carpenter in three months after this day without fail.

The 'lawful damage and protest', and the interest rate of six per cent were standard procedure in Pennsylvania at the time. PMM enforced commercial contracts. 


\section{Merchants embrace the new institution}

If PMM's contract enforcement supported trade expansion, we would expect a large number of merchants among those submitting complaints or being 'sued'. Two sources on Philadelphia merchants exist: First, Gary Nash compiled a list of Philadelphia merchants active in the city between 1682 and 1740. This is based on a wide range of colonial records and probably captures most merchants active in Philadelphia during this time. It comprises 245 merchants, including 131 Quakers. ${ }^{88}$ Of these 131 Quaker merchants, 56 (42.7 per cent) appeared in PMM arbitration cases up to 1740 . They acted either as defendants, plaintiffs, attorneys or were the deceased, whose estates their survivors negotiated.

Second, a PMM ledger containing copies of 482 marriage certificates for the period 1672-1759 survives. ${ }^{89}$ The certificates frequently include husbands' occupations, thus allowing the identification of arbitration parties' occupations. Comparing the names appearing in the arbitration cases to these two sources allowed the identification of 19.6 per cent as merchants. The disproportionate importance of merchants among the conflict parties becomes even clearer when calculated for a single year. In 1690, roughly 330 adult male Friends lived in Philadelphia. ${ }^{90}$ Of these, ten ( 3 per cent) were merchants. ${ }^{91}$ That year, PMM arbitrated nine disputes, involving 21 individuals. Of these, seven, or 33.3 per cent, were merchants.

Clearly, a significant number of Philadelphia Quaker merchants used PMM to solve disputes, and a disproportionate number of arbitration parties were active in trade. Merchants found PMM useful for enforcing contracts, suggesting that it supported trade expansion.

\section{Why did the society of friends resolve disputes?}

But why did PMM become involved in its members' commercial conflicts? The reason was the colony's weak institutional environment. This becomes apparent when comparing the conflicts which PMM negotiated to those brought before the courts. Only one Philadelphia court ledger survives for the early colonial period. It contains Philadelphia county court's cases for the year 1695/1696. That year, the court sat four times each as a court of common pleas and quarter sessions. The court of common pleas that year held equity powers.

The 1695/1696 Philadelphia court ledger was used to compare the types of cases the court decided to those brought before PMM. PMM arbitrated too few cases in 1695/1696 to allow a meaningful comparison. Therefore, PMM cases from the entire period under investigation were used. These included a total of 159 cases. Of these, 92 concerned debt, 33 estates, 12 land disputes, 3 defamation and 19 miscellaneous issues. The court ledger contains 35 cases and lists dispute causes. Comparing the two revealed that the types of cases the court dealt with were identical to those of PMM. In fact, the correlation coefficient, a statistical tool to measure degree of correlation between two sets of cases, is 1.0, indicating the highest possible correlation. Therefore, PMM offered not merely an alternative legal forum. By focusing on equity, it specialised in an area particularly under-served by the state. Moreover, the pattern of cases brought before PMM resembles that 
of contemporary courts elsewhere. Across the Delaware Valley in the period 16801710 , disputes over debts and contracts constituted 82.3 per cent of identifiable issues. $^{92}$ In mid-seventeenth-century London, debt suits accounted for 88 per cent of the business of the court of common pleas, and 80 per cent of that of King's Bench. ${ }^{93}$ Craig Muldrew argued that these figures prove that the courts 'played an important role in economic life'. ${ }^{94}$ Following this logic, the same must be claimed for PMM.

Did PMM arbitrate disputes in order to compensate for the unreliable courts? We can determine this by comparing monthly meeting practices in different locations. The ideal comparison for Philadelphia is London. London was the biggest port at the time and possessed a sophisticated court system. It was also home to the largest single community of Quakers, counting 5,000-8,000 Friends in the late seventeenth and early eighteenth century. ${ }^{95}$ Unlike Philadelphia Yearly Meeting, London Yearly Meeting at the time did not explicitly prohibit Friends from entering law-suits. It, however, repeatedly encouraged Friends to solve disputes by arbitration and 'avoid the scandal of going to law one with another'. ${ }^{96}$ London Friends were organised into six monthly meetings. For five of them, the complete minutes for the period 1682-1772 survive. Searching these records for arbitration cases for sample years of one in ten reveals that while they did occasionally dabble in arbitration, this was far less common than in Philadelphia. Consider the year 1700 . While the London community at the time was at least five times the size of that of Philadelphia, PMM arbitrated nine disputes that year, the five London Monthly Meetings for which records survive, together only one. ${ }^{97}$ What is more, among the Philadelphia minutes of 1690, entries concerning arbitration make up 30 per cent of overall entries. In some months, arbitration constituted the only type of activity entered in the minutes aside from marriages. ${ }^{98}$ Finally, the London Monthly Meetings' involvement in arbitration remained consistently low throughout the period, with three cases at most, in contrast to the high volatility PMM showed in its involvement in arbitration. ${ }^{99}$ Hence, arbitration was not inherently part of Quaker monthly meetings' tasks. Instead, PMM must have adopted the practice for a reason.

If PMM arbitrated disputes because courts were not reliable, we would expect its involvement in arbitration to vary according to the political situation. Figure 1 shows that the distribution of cases is uneven. PMM's first years saw few cases. Their number increased rapidly towards the end of the seventeenth century. Declining briefly in the early 1700 s, they rose again to peak in the 1710-1714 period. They then declined again and reached a nadir in the early 1730s. Rising again briefly during the 1740 s, they consequently petered out.

This trend roughly mirrors the development of political and legal stability in the colony. Within the first years after arrival, Friends learned that the courts were unreliable. Then political conflict began: the crown expropriated Penn, placing the colony under the jurisdiction of non-Quaker New York from 1692 to 1694. Simultaneously, the oath controversy, lasting from the 1690s to about 1720 impeded the courts' functioning. Penn's 1708 bankruptcy and pending threat to sell the colony until 1718 gave Friends cause not to trust the authorities, including courts. In this context, it is also worth noting that Offutt found an increased frequency of civic contempt across the colony, 'as courts struggled to maintain their 


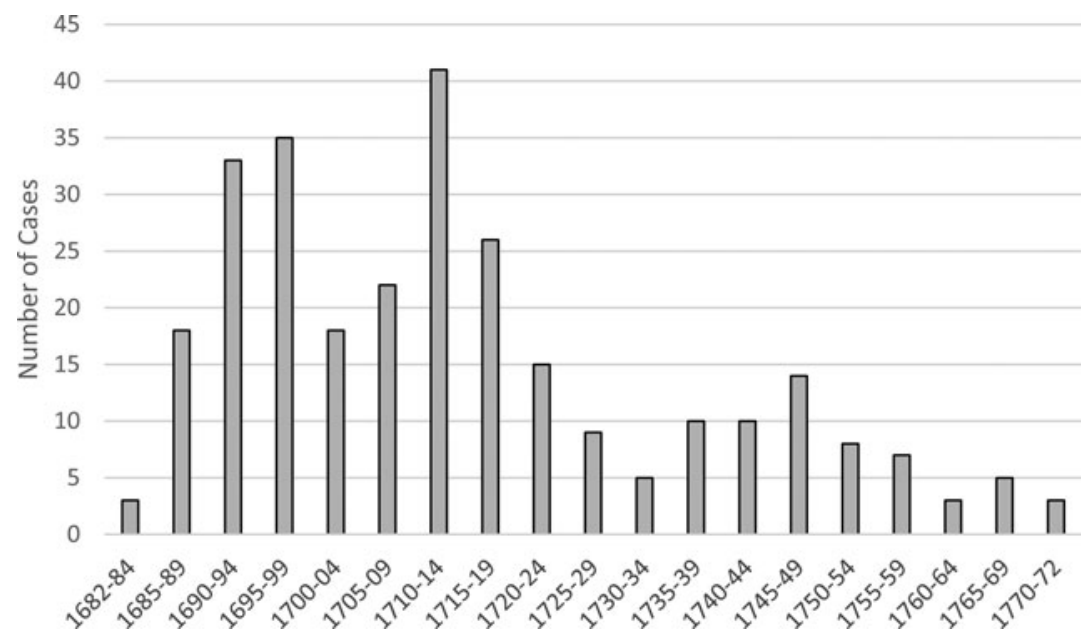

Figure 1. Cases arbitrated by Philadelphia Monthly Meeting.

authority'. ${ }^{100}$ Courts' difficulties to enforce their verdicts gave Friends even more reason to turn to their monthly meeting, instead.

The literature agrees that courts improved significantly from 1720 onwards, as legal instability and political conflict subsided. Importantly, from 1720 to 1736 , a court of equity was active in the colony. In this period, PMM's case load receded. This may reflect Friends' growing trust in the courts. On the other hand, from the 1750s onwards, a major political crisis shook Pennsylvania. During the Seven Years' War, Pennsylvania Quakers quarrelled with the colony's proprietors over military spending. In consequence, Friends eventually withdrew from all public office, including the justice system. ${ }^{101}$ If Friends' use of PMM for dispute resolution merely mirrored the level of trust in, or access to courts, PMM's case load would have increased again in this period. Yet, it did not. While level of accessibility probably mattered, another factor must have been at play in determining PMM's involvement in dispute resolution. As the next section will show, this factor was PMM's ability to enforce its arbitration awards.

\section{How Philadelphia Monthly Meeting harnessed reputation to enforce its verdicts}

The final question regarding PMM's arbitration must address enforcement: For a legal institution to be effective, it requires reliable tools to enforce its verdicts. What instruments did PMM possess to ensure Friends honoured its decisions? Three forms of enforcement emerge from the sources.

First, 'disownment'. This was a form of ostracism, which PMM sometimes applied to Friends who broke its rules or tarnished the Society's reputation. Carli Conklin and Peter Philips attributed much power to disownments, assuming it a harsh measure. ${ }^{102}$ However, if we look at the practice of disownments, a different picture emerges: A disownment consisted of a declaration in front of the community explaining the person's crimes and that PMM no longer considered them a 
member. Disowned Friends were no longer allowed to preach or receive poor relief. They could however continue to attend meetings for worship, and later apply for re-admission. For pious Friends, membership in the Society was important, and many submitted 'self-condemnations' in which they admitted their guilt and apologised. The self-condemnation was publicly read at monthly meetings before the Friend was re-admitted. The nature of the ostracism, as well as reinstatements into membership, suggest that disownments derived at least part of their power from public shaming. The exposure a culprit's misconduct received through the publicity of a disownment caused reputational damage. ${ }^{103}$

PMM recorded hundreds of disownments for disciplinary digressions during the colonial period. ${ }^{104}$ In the context of arbitration, disownment appears 18 times. ${ }^{105}$ PMM actually 'executed' a disownment in eight of these instances. ${ }^{106}$ Twice the parties reached an agreement immediately after PMM threatened disownment. ${ }^{107}$ The remaining cases dragged on, some of them occasioning several threats of disownment before disappearing from the minutes. ${ }^{108}$

A second enforcement instrument was PMM's granting plaintiffs permission to approach the public courts. The minutes include 47 such instances. While the Discipline prohibited Friends from entering law-suits without permission, we know that Pennsylvania Quakers litigated regularly without facing repercussions from their monthly meetings. ${ }^{109}$ Yet, Friends sometimes approached PMM, explaining their grievance over another Friend's conduct and requesting 'liberty to go to law'. If they did not have to fear repercussions for appealing to court of their own accord, why did they bother asking PMM's permission? Most likely, this served to threaten defendants. ${ }^{110}$ By seeking PMM's permission to sue, plaintiffs communicated the seriousness of their intention, while still avoiding the disadvantages of a law suit. PMM met more regularly than the courts, shortening the waiting periods a person wanting to litigate would otherwise have to endure. Approaching PMM first might also save court fees, as the meeting's service was free. As Isaac Norris put it in a letter to a Friend in England, whose claims on an inheritance he was representing: 'I had thoughts of entering an attachmt and recover it legally but that will be chargeable \& therefore apply'd again to our meeting who have appointed Two Ffrds to assist me'. ${ }^{111}$ The 1,717 case of Mary Howard illustrates this further: In that instance, Richard Moore, as attorney to one Henry Childs of Maryland, issued a complaint with PMM against Mary Howard for refusing to settle a debt. PMM appointed two Friends to 'endeavour to persuade her to pay the money'. ${ }^{112}$ The following month, 'she appearing justly indebted to the said Childs, the same friends are continued, and desired to put her upon making pay to said Childs (...), or otherwise to let her know, that he or Richd. Moore on his behalf may take a legal course against her'. ${ }^{113}$ Four weeks later the case was minuted as 'ended'. ${ }^{114}$ Apparently, the threat worked. There were also multiple cases which disappeared from the minutes without formal ending. In these instances, we do not know whether the dispute was settled as a consequence of PMM's threat, or whether Friends in fact continued their conflict in court. As Friends employed this method quite frequently, they appear to have thought it useful.

Friends used disownments and law-suits as threats. Both practices involved a high degree of publicity, they shone a light on the conflict parties and their behaviour. This indicates that reputation played an important role in PMM's resolution 
of disputes. Indeed, the importance of reputation in the early modern world cannot be overstated. Its role in long-distance trade has been discussed above. No less important, a person's reputation determined her or his standing in their local community, both socially and economically. With little currency in circulation, economic transactions, from intercontinental trade to buying bread at the local baker's, were based on credit. ${ }^{115}$ Whether others would grant you credit or not depended on whether they trusted you to repay them. Their trust depended on a person's reputation. If someone's reputation was tarnished, others would refuse to deal with them.

The impact of spoken words is further reflected in the use and practice of law. American colonists turned to courts to salvage their reputations after having been slandered. Slander suits included instances of 'charging the target with fraudulent or deceptive business practices. ${ }^{116}$ Mary Beth Norton found that 'The two epithets most commonly employed by men against other men, "rogue" and "knave", both implying a lack of trustworthiness' ${ }^{117}$ In early colonial Pennsylvania, accusations of commercial malfeasance were among the three most common causes of slander accusations. ${ }^{118}$ The frequency of slander suits reflects the damage people feared loss of reputation would do to their social and economic lives.

Colonial courts, in turn, used the force of reputation to punish crimes. ${ }^{119}$ In seventeenth-century Maryland, courts sentenced those convicted of slander to apologise publicly to the person $s /$ he had slandered and explain that their accusations were false. ${ }^{120}$ Pennsylvania law 'mandated that those found guilty of fraud (...) have their names published as frauds and that disorderly people be publicly termed "Breakers of the Peace". ${ }^{121}$

A connection between reputation and arbitration has been suggested by Bruce Mann's 1984 study of dispute resolution in seventeenth-century Connecticut. He showed that formal dispute resolution mechanisms replaced informal arbitration as the local population's size and composition changed. ${ }^{122}$ His illuminating research predates more recent work on private order institutions for contract enforcement, and a possible role of reputation mechanisms for the enforcement of arbitration awards remains unexplored. When disputes were arbitrated in early modern Scotland and England, Margo Todd argued more recently, publicity provided by 'large numbers of witnesses' ensured that 'the settlement would be kept, since violating an agreement witnessed by the whole neighbourhood would bring charges of duplicity and undermine reputation'. ${ }^{123}$

It is here that the key to PMM's success as a legal forum lies: Its most powerful tool was the ability to tarnish a malfeasant Friend's reputation. In order to enforce its arbitration awards, PMM deliberately employed reputation mechanisms, in a fashion similar to that of American courts. According to Marc Galanter, the ability to provide stigma is among courts' most powerful instruments, and courts' impact on disputes derives largely from their ability to disseminate information. ${ }^{124}$ Thanks to the Atlantic-wide scope of the Society of Friends' formal organisation, PMM could disseminate information further, making its arbitration particularly useful to long-distance merchants.

PMM developed means to gather, verify and disseminate information about individual Friends' conduct. First, it appointed and monitored arbitrators. These investigated disputes and reported back to PMM regularly. Through these 
investigations PMM ensured that the information it obtained was accurate. Next, PMM diffused this information locally and internationally. It discussed cases at its monthly gatherings, which were open to the public. As mentioned above, merchants tried to avoid taking disputes to courts because they feared the damage to reputation this could cause. ${ }^{125}$ PMM made use of this fear. Discussing a dispute at PMM increased its visibility in the community, as well as the (mis-)conduct of the dispute parties. It thereby exerted pressure on the defendants.

PMM, furthermore, transmitted information through the Society of Friends' Atlantic-wide organisation of meetings. According to its minutes, PMM corresponded formally with other monthly meetings in America and Europe in order to solve conflicts. In 1690, PMM contacted the Monthly Meeting of Hartshaw, Lancashire, regarding the payment of maintenance by some Lancashire Friends to Thomas Hodge in Philadelphia. They asked Hartshaw Friends

that they would be pleased to stir up those Friends concerned to send over (...) the interest of the foresaid money for the reasonable charges of the

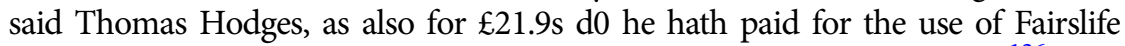
Hodges with the interest thereof, which also hath been refused hitherto. ${ }^{126}$

Alternatively, if there was a conflict between a Philadelphia Friend and a Friend belonging to another monthly meeting not too far away, representatives of both meetings would meet to settle the dispute. In 1696, PMM noted:

There being a matter of difference brought to this meeting by Ralph Jackson between himself and Josiah Ferne belonging to the monthly meeting of Derby. In order to the putting an end thereunto, this meeting requests John Kinsey \& David Lloyd to meet with two Friends appointed by the monthly meeting of Derby for the same purpose, that they may end it if possible. ${ }^{127}$

Those corresponding monthly meetings would then discuss the conflicts as well, increasing the circle of those who learned PMM's verified information.

Furthermore, many of PMM's officers were merchants. A list of names of those acting as officers in arbitration cases for one year in every ten includes 70 individuals. The sources discussed above allowed for the identification of 39 of these, 55.7 per cent, as merchants. They maintained business correspondence with agents across the Americas and Europe. While their surviving correspondence contains no evidence of their passing on information gleaned specifically from PMM arbitrations, they do share information about each other's conduct of business and character regularly with their correspondents. ${ }^{128}$ Jonathan Dickinson, for instance, appeared as an arbitrator in 1698. ${ }^{129}$ His letters include addressees in London and Jamaica. ${ }^{130}$ Officer Samuel Carpenter traded with Barbados, Samuel Richardson with Boston and New York. ${ }^{131}$ It is unlikely that these merchants, concerned with sharing important information with their correspondents, would have omitted intelligence gleaned from arbitration procedures.

Through its investigations PMM ensured that the information it obtained was more reliable than rumours circling informally. Through the public discussion of 
this information at monthly meetings in Philadelphia and elsewhere, and its 'leaking' by officers, the Society of Friends reinforced reputation mechanisms.

PMM, moreover, showed concern over the reputational damage its procedures might cause. In 1687, John Ithell accused merchant Robert Turner of malfeasance. PMM thereupon 'appointed some friends to hear the matter in difference between them'. These Friends reported back that, according to the best of their judgement, the said John Ithell had 'wrongfully charged him the said Robert Turner. ${ }^{132}$ PMM ordered further investigations, and two months later, it directed several Friends to 'draw up a certificate $(\ldots)$ to be sent to England \& Ireland for the clearing him (Robert Turner) of those scandalous reports that hath been spread concerning him in those parts to his defamation'. ${ }^{13}$

A comparison of the development of arbitration cases with Philadelphia's population reveals more evidence. As discussed above, there is a certain correlation between the numbers of cases PMM arbitrated, and political crises in the colony. Figures 2 and 3 demonstrate a stronger, negative correlation between three factors: PMM's case load and case outcomes, on the one hand, and Philadelphia's demographic development, on the other.

From the late 1710s onwards, PMM's case load decreased dramatically. Moreover, cases' outcomes changed. Overall, 48 per cent of cases disappeared from the minutes without a formal ending, that is, the minutes do not mention them for 12 consecutive months. This number closely resembles that for Delaware Valley courts. ${ }^{134}$ Figure 2 shows that the formally ended cases were distributed unevenly. Constituting roughly 50 per cent until about 1720 , their proportion increased rapidly thereafter.

The decline in PMM's case load and the number of cases without formal ending coincided with the exponential increase in migration to Philadelphia. Local Quaker merchant James Logan in 1717 described this development as follows:

... there are divers hundreds, arrived here who have not one word of English and bring no credentials with them ( ... ) the numbers of these strangers have given some uneasiness to the inhabitants here, \& will encrease it, if they continue thus their swarms. ${ }^{135}$

The changes in PMM's handling of cases were not due to its limited capacity. It expanded its work dramatically during this period. This is evidenced by the number of pages of minutes for each session. While the Philadelphia Quaker population roughly doubled between 1690 and 1760, the length of PMM's minutes increased about 26-fold. ${ }^{136}$ This demonstrates an intense increase in PMM's effort of administration per capita. However, it chose not to use this extra capacity for conflict arbitration, instead focusing on other matters.

The new immigrants differed from their predecessors. First of all, they were not Quakers. ${ }^{137}$ Ergo, they would not participate in monthly meetings and witness arbitration proceedings there. They were also less likely to learn of information discussed in Quaker meetings from other Quakers. Additionally, many of them were German and spoke no English. ${ }^{138}$ As Jack Marietta and G.S. Rowe put it, the new arrivals' ethnic and linguistic diversity 'diluted the homegeneity of the province'. ${ }^{139}$ Population growth, combined with the change in religious and 


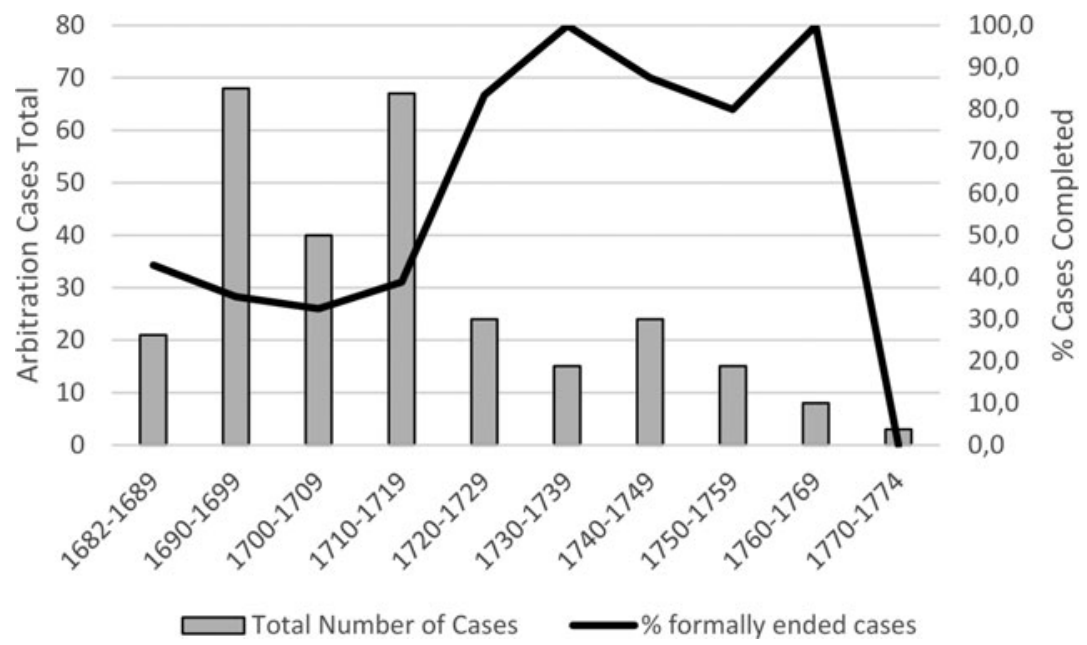

Figure 2. Completed arbitration cases. Sources: Haverford Special Collections, Philadelphia Monthly Meeting minutes and Billy G. Smith, 'Death and life in a colonial immigrant city: a demographic analysis of Philadelphia', The Journal of Economic History 37, 4 (1977), 863-89.

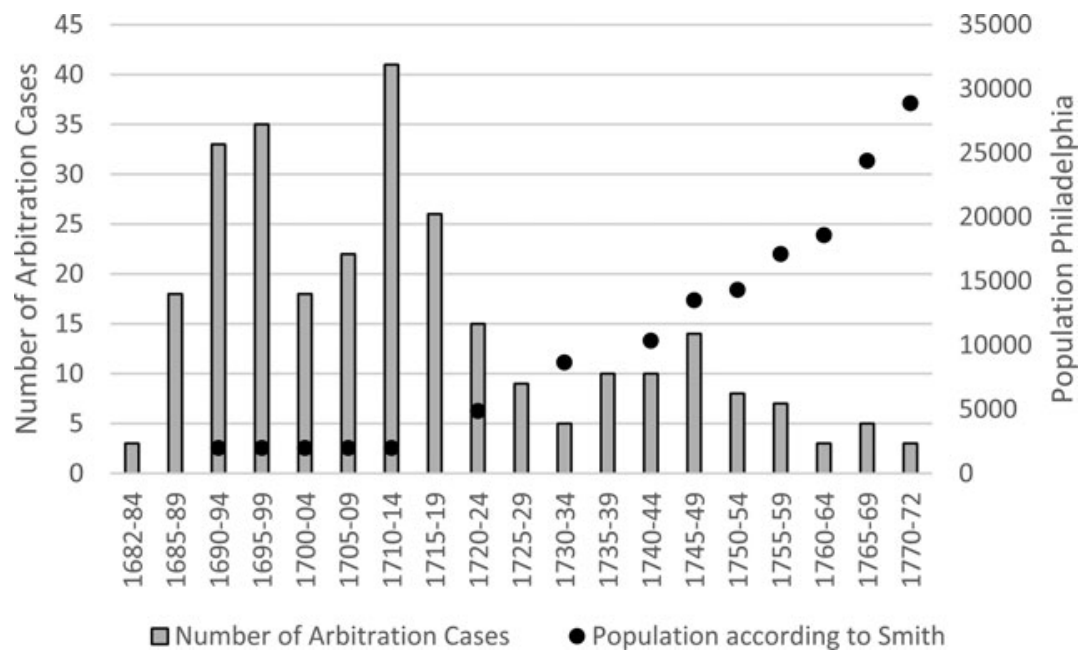

Figure 3. Meeting arbitration cases and Philadelphia population. Sources: Haverford Special Collections, Philadelphia Monthly Meeting minutes and Billy G. Smith, 'Death and life in a colonial immigrant city: a demographic analysis of Philadelphia', The Journal of Economic History 37, 4 (1977), 863-89.

linguistic composition, must have posed a barrier to the flow of information. Thereby it lowered the possible impact of reputation mechanisms. Social pressure exerted through everyone in town learning about alledged misconduct would have diminished significantly. The degree of public shaming for malpractice diminished, and thereby the reputation mechanism's power to pressure conflict parties into giving in and finding informal solutions. Consequently, PMM's power to 
enforce contracts faded. Friends noticed this and began searching for alternative forms of contract enforcement. As discussed above, Pennsylvania's courts improved from about 1720 onwards, as political and legal stability finally arrived in the colony. Likely, Friends now turned to the courts to solve disputes between them.

\section{Conclusion}

Research on Atlantic trade expansion has been strongly influenced by the New Institutional Economists. For the NIE, long-distance trade expansion is contingent on the replacement of private order, communitarian institutions by public order institutions provided by the state. Public order institutions could better enforce contracts and protect property rights because they were backed by the state, who, holding sovereignty throughout its territory, would enforce court's verdicts. This lowered transaction costs and enabled trade to expand. In the American colonies the state was underdeveloped, public courts unreliable and the collection of debts notoriously difficult. In spite of this, trade in the Atlantic grew a great deal. Philadelphia Quaker merchants were prominent in the colonial trades from the colony's earliest days, and the city soon emerged as one of North America's greatest ports. In the face of its weak institutions, Philadelphia's commercial ascent needs explaining.

This paper has argued that the solution to the puzzle of Philadelphia's success lies in the realm of religion. Religion as the basis for informal trading networks in the Atlantic is well established. The PMM records, however, show that religion did more than provide the basis for informal networks. It also supported trade through formal institutions. PMM arbitrated commercial disputes among merchants. It specialised in equity, a branch of law that while important for the enforcement of commercial contracts, was underserved in the colony. PMM enforced its arbitration awards by highlighting commercial conflicts within the community. It did this locally, through its monthly gatherings, as well as through its formal organisation of meetings across the English/British Atlantic world. This placed pressure on the parties: In order to limit reputational damage, they had to come to an agreement quickly. As Philadelphia grew in size and diversity, the flow of information through informal channels became more difficult. PMM lost the power to enforce its decisions, and consequently its popularity among Friends.

PMM acted as a legal forum that specialised in settling commercial disputes between its members. In so doing, the Society of Friends de facto provided law in the colony. In colonial Pennsylvania, 'Quaker law' existed as an alternative to 'state law'. As Quaker merchants resorted to PMM often, we can deduce that it played an important role for their businesses and thereby the growth of Philadelphia's trade. Rather than a hinderance, legal fragmentation was at the root of colonial Philadelphia's commercial success.

What are the implications of this finding for research on pre-modern trade expansion? The growth of pre-modern long-distance trade depended primarily on two sets of actors. These were first, the chartered trading companies, and second, religious diasporas.

It is well-established that the English East India Company (EIC) and Dutch East India Company (VOC) had sovereignty in Asia and jurisdiction over English and 
Dutch subjects in 'their' territories. ${ }^{140}$ They made and enforced law through their own institutions. While EIC regulations were formally supposed to be in accordance with English law, de facto company legal practice was independent. ${ }^{141}$ In practice, European commerce in the Indian Ocean depended largely on the law of non-state actors.

Religious diasporas formed the second spearhead of trade expansion. The most prominent of these included Armenians, Sephardim and Quakers. Sebouh Aslanian has located an institution very similar to the Quaker Monthly Meeting in Safavid New Julfa. The 'Assembly of Merchants' supported Armenian merchants' global trade networks by gathering information about merchants' behaviour overseas and disseminating this among the community. Thereby it reinforced reputation mechanisms. $^{142}$

Research by Nuala Zahedieh, Jessica Roitman and Hugo Martins has shown that Sephardi merchants in Europe and the American colonies also benefited from private courts. Communities from Hamburg to Curacao elected boards of elders - the Mahamad - who ensured community members' compliance with religious rules. They also arbitrated commercial conflicts according to formally written rules. How they enforced their decisions, and what role reputation played in this context has yet to be fully explored. The records do, however, show striking similarities to PMM in terms of the causes of conflicts they dealt with and the procedures they followed. ${ }^{143}$ This suggests that the creation of legal forums for commercial dispute resolution was not restricted to the Society of Friends, but a common feature of premodern religious trading diasporas. If so, this would help explain the prominence of religious diasporas in long-distance trade.

It would appear that non-state law played an important role not only for Philadelphia merchants, but pre-modern trade expansion in general. Why was that? Colonies, whether those of European states or trading companies, were more diverse than societies in the European mother countries. Lauren Benton and others have pointed out that this diversity gave rise to conflicts which were novel to the metropole, and for which European law had no ready solutions. Law developed locally by those with first-hand experience of colonial life and economy was more likely to serve the colonists' purposes. It was also cheaper for metropolitan governments than developing new legal structures and forcing these upon colonial populations.

Second, the diaspora communities so crucial to trade expansion often had a history of oppression. When first settling in Pennsylvania in the 1680s, Friends were still suffering persecution in England. While they had the privilege of shaping legal institutions in Pennsylvania, the 'oath controversy' and threat of expropriation suggested that the situation could turn with public courts becoming instruments of oppression once again. The dissenting protestant founders of other American colonies shared these experiences. Sephardi Jewish merchants carried with them the heritage of the inquisition and flight from the Iberian Peninsula. While settling in various European cities, they continued to face discrimination and harassment from both the public and state authorities. These minorities' experience with state courts was often one of imprisonment and property confiscations - a far cry from the image North et al. paint of the helpful institution that enforces contracts and protects property rights. Under these circumstances, it made sense for persecuted minorities to prefer alternative legal forums to public courts. 
A final reason for resorting to non-state law lay in European trade policy. Mercantilism forbade subjects to trade with destinations outside the empire, heavily limiting commercial opportunities. We now know that merchants often ignored these prohibitions and that illegal inter-imperial trade was substantial. ${ }^{144}$ Bernard Bailyn called smuggling 'integral to the working of the Atlantic system. ${ }^{145}$ Illegal commerce depended on the enforcement of contracts, too. Self-evidently, merchants could not turn to state courts for help with errant payments or faulty wares. Non-state legal forums would have been one way to overcome these challenges.

Philadelphia's Quaker legal forum suggests that we need to reassess the role of both religion and the state for trade expansion. Contrary to what North et al. have argued, the rise of strong states and public order institutions was not the basis for early modern trade expansion. Religious diasporas leading Atlantic trade expansion, including the Quakers, built their trading empires by drawing on alternative law. Rather than strong central governments, the key to trade expansion and economic growth in the Atlantic was institutional diversity.

Acknowledgements. For their input and support I thank Yadira Gonzalez de Lara, Daniel Strum and the participants of the 'Institutional foundations of pre-modern long-distance trade' meetings, Nuala Zahedieh and the participants of the 'Economic and Social History of the Early Modern World' seminar, Amalia Kessler, Patrick Wallis, the Historical Society of Pennsylvania, Alberto Winterberg and three anonymous reviewers.

\section{Notes}

1 Daron Acemoglu, Simon Johnson and James A. Robinson, 'The rise of Europe: Atlantic trade, institutional change and economic growth', American Economic Review 95 (2005). Eric Eustace Williams, Capitalism and Slavery (1944). Kenneth Morgan, Slavery, Atlantic trade and the British economy, 16601800 (Cambridge, 2000).

2 Ha-Joon Chang, 'Institutions and economic development: theory, policy and history', Journal of Institutional Economics 7, 4 (2011); Robin Pearson and David Richardson, 'Social capital, institutional innovation and Atlantic trade before 1800', Business History 50, 6 (2008); Acemoglu, Johnson and Robinson, 'The rise of Europe'; Daron Acemoglu and Simon Johnson, 'Unbundling institutions', Journal of Political Economy 2013, 5 (2005); Chang, 'Institutions and economic development'; Nathan Nunn, 'The importance of history for economic development', Annual Review of Economics 1, 1 (2009); Douglass C. North and Robert Paul Thomas, The rise of the western world: a new economic history (London, 1973); Douglass C. North, Structure and change in economic history (New York and London, 1981); Douglass C. North, Institutions, Institutional change and economic performance (Cambridge, 1990); Daron Acemoglu, Simon Johnson and James A. Robinson, 'Reversal of fortune: geography and institutions in the making of the modern world income distribution', The Quarterly Journal of Economics 1174, 4 (2002); Austin Gareth, "The "Reversal of Fortune" thesis and the compression of history: perspectives from African and comparative economic history', Journal of International Development 20, 8 (2008); Douglass North and Barry Weingast, 'Constitutions and commitment: the evolution of institutions governing public choice in seventeenth-century England', The Journal of Economic History 49, 4 (1989); Abhijit Banerjee and Lakshmi Iyer, 'History, institutions and economic performance: the legancy of colonial land tenure systems in India', The American Economic Review 95, 4 (2005).

3 Avner Greif, Institutions and the path to the modern economy. Lessons from Medieval trade, political economy of institutions and decisions (Cambridge and New York, 2006), 343, 344, 346.

4 Ibid., 343.

5 North and Thomas, The rise of the western world, 7; see also North, Institutions, Institutional change and economic performance.

6 North, Institutions, Institutional change and economic performance, ch. 7. 
7 Oscar Gelderblom and Regina Grafe, 'The rise, persistence and decline of merchant guilds. Re-thinking the comparative study of commercial institutions in pre-modern Europe', Journal of Interdisciplinary History XL, 4 (2010); Regina Grafe, 'On the spatial nature of institutions and the institutional nature of networks in the Spanish Atlantic', Culture and History 3, 1 (2014); Daniel Strum, 'Institutional choice in the governance of the early Atlantic sugar trade: diasporas, markets, and courts', The Economic History Review 72, 4 (2019).

8 David Hancock, 'A revolution in trade: wine distribution and the development of the infrastructure of the Atlantic market economy, 1703-1807', in John McCusker and Kenneth Morgan eds., The early modern Atlantic economy (Cambridge, 2000); Richard L. Kagan and Philip D. Morgan, Atlantic diasporas: Jews, Conversos, and Crypto-Jews in the age of mercantilism, 1500-1800 (2009); Nuala Zahedieh, 'Defying mercantilism: illicit trade, trust, and the Jamaican Sephardim, 1660-1730', The Historical Journal 61, 1 (2018); J. F. Bosher, 'Huguenot merchants and the protestant international in the seventeenth century', The William and Mary Quarterly 50, 1 (1995); Jordan Landes, The role of London in the creation of a Quaker transatlantic community in the late seventeenth and eighteenth centuries (London, 2011).

9 Isaac Norris letter book vol. V, to Martha Baker, 7th 8ber 1715, 520. Quakers often did not use Latin dates. Instead, they numbered days and months: 1st month, 2nd month, 1st day, 2 nd day, etc. This article employs the dates as used in the primary sources.

10 Oscar Gelderblom, Cities of commerce: the institutional foundations of international trade in the low countries, 1250-1650 (2013). 11, arbitration, mediation as a substitute for litigation, 105.

11 Christian Burset, 'Merchant courts, arbitration, and the politics of commercial litigation in the eighteenth-century British Empire', Law and History Review 34, 3 (2016); Claire Priest, 'Law and commerce, 1580-1815', in Michael Grossberg and Christopher Tomlins eds., (Columbia and South Carolina, 2008): 412 on the English north American colonies, 141. On the colonies: William C. Jones, 'An inquiry into the history of the adjudication of mercantile disputes in Great Britain and the United States', The University of Chicago Law Review 25, 3 (1958); Bruce J. Mann, 'The formalization of informal law: arbitration before the American revolution', NYUL Review 59 (1984); On widespread use of arbitration in seventeenth- and eighteenth-century Maryland: James Oldham and Su Jin Kim, 'Arbitration in America: the early history', Law and History Review 31, 1 (2013); In early modern Scotland and England, arbitration became the preferred means of dispute resolution for all kinds of conflicts, not only commercial. See Margo Todd, 'For eschewing of trouble and exorbitant expense: arbitration in the early modern British Isles symposium', Journal of Dispute Resolution 2016, 1 (2016); Derek Roebuck, 'The English inheritance-what the first American Colonists knew of mediation and arbitration', Journal of Dispute Resolution 2016, 2 (2016). 12 Horwitz in a highly influential work located this change in the post-revolutionary area, but primarily because he did not consult manuscript sources: Morton J. Horwitz, The transformation of American Law, 1780-1860 (Cambridge, Mass., 1977). Legal scholars have since moved the period of change to court-related dispute resolution into the early and mid-eighteenth century: Eben Moglen, 'Commercial arbitration in the eighteenth century: searching for the transformation of American law', The Yale Law Journal 93 (1983), 138,147 . In Britain, the opposite happened: arbitration grew more important than courts in this period: Todd, 'For eschewing of trouble and exorbitant expense'.

13 Mann, 'The formalization of informal law', 447, explains use of bonds in Connecticut, but says they did not enforce arbitration awards, but raised the cost of ignoring them; Edward Peter Stringham and Todd J. Zywicki, 'Rivalry and superior dispatch: an analysis of competing courts in medieval and early modern England', Public Choice 147, 3/4 (2011), 517; Edward Powell, 'Arbitration and the law in England in the late middle ages: the Alexander prize essay', Transactions of the Royal Historical Society 33 (1983).

14 John Griffiths, 'What is legal pluralism?', The Journal of Legal Pluralism and Unofficial Law 18, 24 (1986); Marc Galanter, 'Justice in many rooms: courts, private ordering, and indigenous law', The Journal of Legal Pluralism and Unofficial Law 13, 19 (1981).

15 Griffiths, 'What is legal pluralism?'; Sally Engle Merry, 'Legal pluralism', Law \& Society Review 22 (1988); Galanter, 'Justice in many rooms'.

16 Griffiths, 'What is legal pluralism?', 36.

17 Sally Falk Moore, 'Law and social change: the semi-autonomous social field as an appropriate subject of study', Law \& Society Review 7, 4 (1973), 722.

18 Ibid., 720.

19 Griffiths, 'What is legal pluralism?'. 
20 Moore, 'Law and social change: the semi-autonomous social field as an appropriate subject of study', 744; Philip Loft, 'A tapestry of laws: legal pluralism in eighteenth-century Britain', The Journal of Modern History 91, 2 (2019), 280; See also Galanter, 'Justice in many rooms'; Paolo Sartori and Ido Shahar, 'Legal pluralism in Muslim-majority colonies: mapping the terrain', Journal of the Economic and Social History of the Orient 55, 4-5 (2012).

21 Ann M. Carlos, Edward Kosack and Luis Castro Penarrieta, 'Bankruptcy, discharge, and the emergence of Debtor rights in eighteenth-century England', Enterprise \& Society 20, 2 (2019), 485.

22 Burset, 'Merchant courts, arbitration, and the politics of commercial litigation in the eighteenth-century British Empire', 631.

23 Ibid., 636.

24 Amalia D. Kessler, 'Marginalization and myth: the corporatist roots of France's forgotten elective judiciary', The American Journal of Comparative Law 58, 3 (2010).

25 Loft, 'A tapestry of Laws'.

26 Richard J. Ross and Philip J. Stern, 'Reconstructing early modern notions of legal pluralism', in Legal pluralism and empires, 1500-1850 (NYU Press, 2013), 110-1; Albrecht Cordes and Philipp Höhn, 'Extra-legal and legal conflict management among long-distance traders (1250-1650)', in The Oxford handbook of European legal history 521, 533; Richard J. Ross, 'Puritan godly discipline in comparative perspective: legal pluralism and the sources of "intensity"', The American Historical Review 113, 4 (2008); Loft, 'A tapestry of laws'; S. R. Epstein, Freedom and growth: the rise of states and markets in Europe, 1300-1750 (2000), 14.

27 Ross and Stern, 'Reconstructing early modern notions of legal pluralism', 112.

28 Epstein, Freedom and growth, 6. Epstein made this argument for continental Europe, Loft has since expanded it to England: Loft, 'A tapestry of laws'.

29 Epstein, Freedom and growth, 14.

30 Pihlajamäki Heikki et al., English law and its expansion, 831.

31 Lauren Benton, 'The legal regime of the South Atlantic World, 1400-1750: jurisdictional complexity as institutional order', Journal of World History 11, 1 (2000), 55; see Lauren Benton and Richard J. Ross, 'Empires and legal pluralism: jurisdiction, sovereignty, and political imagination in the early modern world', in Legal pluralism and empires, 1500-1850 (2013).

32 Philip J. Stern, The company-state: corporate sovereignty and the early modern foundations of the British Empire in India (2011); Adam Clulow, The company and the Shogun: the Dutch encounter with Tokugawa Japan (2014).

33 Todd, 'For eschewing of trouble and exorbitant expense', 14.

34 Philadelphia Yearly Meeting Discipline 1719, 33.

35 Ibid., 35.

36 Horwitz, The transformation of American law, 1780-1860. Horwitz has moreover argued that it was the Quaker influence was the reason PN was arbitration friendly. Carli N. Conklin, 'Transformed, not transcended: the role of extrajudicial dispute resolution in Antebellum Kentucky and New Jersey', American Journal of Legal History 48, 1 (2006).

37 Conklin, 'Transformed, not transcended'; See also Phillips, 'Ancient and comely order'.

38 F. Peter Phillips, 'Ancient and comely order: the use and disuse of arbitration by New York Quakers', Journal of Dispute Resolution 2016, 1 (2016).

39 Sahle, Esther. "Quakers, coercion, and pre-modern growth: why Friends' formal institutions for contract enforcement did not matter for early modern trade expansion." The Economic History Review 71, 2 (2018): $418-436$.

40 Carole Dale Spencer, 'Quakers in theological context', in Stephen W. Angell and Pink Dandelion eds., The Oxford handbook of Quaker studies (Oxford, 2013); Stephen W. Angell, 'God, Christ, and the Light', in Stephen W. Angell and Pink Dandelion eds., The Oxford handbook of Quaker studies (Oxford, 2013).

41 Rosemary Anne Moore, The light in their consciences: early Quakers in Britain, 1646-1666 (University Park - PA and Pennsylvania State University Press - Great Britain, 2000), 144.

42 Fredrick Tolles, 'The trans-Atlantic Quaker community in the seventeenth century', The Huntington Library Quarterly 14, 3 (1951).

43 There were also preparatory meetings. These prepared the work of the monthly meetings. As they did not keep records, we know little about them. 
44 Bill Stevenson, 'The social integration of post-restoration dissenters, 1660-1725', in Margaret Spufford ed., The world of rural dissenters 1520-1725 (Cambridge, 1995); John Miller, “A suffering people": English Quakers and their neighbours, c.1650-c.1700', Past and Present 188, 1 (2005), 71-103.

45 Miller, 'A suffering people', has shown that in some places, persecution continued well into the eighteenth century.

46 Carl Bridenbaugh, 'The old and new societies of the Delaware Valley in the seventeenth century', The Pennsylvania Magazine of History and Biography 100, 2 (1976), 159, 168; David Hackett Fischer, Albion's seed: four British folkways in America, vol. 1 (Oxford, 1991), 1, 5, 560; William M. Offutt, Of 'good laws' and 'good men': law and society in the Delaware Valley, 1680-1710 (1995), 5; Barry Levy, Quakers and the American family: British settlement in the Delaware Valley (Oxford, 1992), 6, 14; Levy, Quakers and the American family, 6, 16; J. T. Lemon, The best poor man's country: early Southeastern Pennsylvania (Johns Hopkins University Press, 2002); Bridenbaugh, 'The old and new societies of the Delaware Valley in the seventeenth century', 159.

47 Gary B. Nash, Quakers and politics: Pennsylvania, 1681-1726, New ed. (Boston, Mass., 1993), 56.

48 Nash, Quakers and politics, 56. On Pennsylvania's early and unusual economic success, see also Fischer, Albion's seed, 560; Bridenbaugh, 'The old and new societies of the Delaware Valley in the seventeenth century', 145-63; Barry Levy, Quakers and the American family; Offutt, Of 'good laws' and 'good men', 5.

49 John J. McCusker and Russell R. Menard, The economy of British America, 1607-1789, 2nd print. ed. (Chapel Hill, NC, 1986), 205.

50 Jack D. Marietta, The reformation of American Quakerism, 1748-1783 (Philadelphia, 1984), 47.

51 Billy G. Smith, 'Death and life in a colonial immigrant city: a demographic analysis of Philadelphia', The Journal of Economic History 37, 4 (1977).

52 Nash, Quakers and politics, 302, 322.

53 Marietta, The reformation of American Quakerism, 1748-1783, 47.

54 On frequent legal changes, see, for instance: Marylynn Salmon, 'Notes and documents: the court records of Philadelphia, Bucks, and Berks counties in the seventeenth and eighteenth centuries', The Pennsylvania Magazine of History and Biography 107, 2 (1983). On Pennsylvania courts' development, see, for instance: Carli Conklin, 'A variety of state-level procedures, practices, and policies: arbitration in early America', Journal of Dispute Resolution 55 (2016); Edwin B. Bronner, 'Philadelphia county court of quarter sessions and common pleas, 1695', The American Journal of Legal History 1, 1 (1957); Lawrence Lewis, 'The courts of Pennsylvania in the seventeenth century', The Pennsylvania Magazine of History and Biography 5, 2 (1881), 2.

55 Offutt, Of 'good laws' and 'good men', 3.

56 William Offutt, 'The Atlantic rules: the legalistic turn in colonial British America', in Elizabeth Mancke and Carole Shammas eds., The creation of the British Atlantic world. Anglo-America in the trans-Atlantic world (Baltimore, 2005), 174.

57 Jack D. Marietta and G. S. Rowe, Troubled experiment: crime and justice in Pennsylvania, 1682-1800 (Philadelphia, PA, 2006), 20.

58 A. Laussat, An essay on equity in Pennsylvania (Lawbook Exchange, 1826/2002), 22; Equally: Sydney George Fisher, 'The administration of equity through common law forms in Pennsylvania', in Committee of the Association of American Law Schools ed., Select essays in Anglo-American legal history (Boston, 1908); Marietta and Rowe, Troubled experiment, 20.

59 Salmon, 'Notes and documents', 251-5.

60 For history of equity powers in Pennsylvania courts, repeatedly issued and repealed, see Spencer R. Liverant and Walter H. Hitchler, 'A history of equity in Pennsylvania', Dickinson Law Review 37 (1933); William Henry Rawle, Equity in Pennsylvania: a lecture delivered before the Law Academy of Philadelphia, February 11, 1868 (Philadelphia, 1868), especially 10-20.

61 Stanley Katz, 'The politics of law in colonial America: controversies over chancery courts and equity law in the eighteenth century', Perspectives in American History 5 (1971), 266.

62 Amalia D. Kessler, Inventing American exceptionalism: the origins of American adversarial legal culture, 1800-1877 (Yale University Press, 2017), 53.

63 Ibid., 54.

64 Katz, 'The politics of law in colonial America', 271. The Pennsylvania Council, when deciding on the establishment of an equity court in 1720 , also emphasised that it had found a way for it to operate 'safely'. 
Samuel Hazard, Minutes of the provincial council of Pennsylvania: from the organization to the termination of the proprietary government [Mar. 10, 1683-Sept. 27, 1775], vol. 2 (J. Severns, 1852), 106.

$65 \mathrm{Katz}$, 'The politics of law in colonial America', 264.

66 Ibid., 265.

67 James Irwin Brownson, Equity in Pennsylvania from the historical point of view (Miami, 2019), 17.

68 Lewis, 'The courts of Pennsylvania in the seventeenth century', 147.

$69 \mathrm{Katz}$, 'The politics of law in colonial America', 267-8.

70 Brownson, Equity in Pennsylvania from the historical point of view, 22.

71 William H. Lloyd, 'The courts of Pennsylvania in the eighteenth century prior to the revolution', University of Pennsylvania Law Review and American Law Register 56, 1 (1908), 34; Marietta and Rawle, Troubled experiment 21-2.

72 Marietta and Rowe, Troubled experiment, 30.

73 Ibid., 32.

74 Offutt, Of 'good laws' and 'good men', 3; on defence finances: Bronner, 'Philadelphia county court of quarter sessions and common pleas, 1695', 459.

75 Marietta and Rowe, Troubled experiment, 33.

76 Cordes and Höhn, 'Extra-legal and legal conflict management among long-distance traders (12501650)'.

77 Offutt, Of 'good laws' and 'good men', 69. Offutt says over 40 per cent of litigants were Friends. The method by which he identifies them remains unclear. The court records provide only the parties' names, but no further information by which to identify them in the Quake records. Presumably, Offutt identified everyone in the records as a Friend, if a Friend by the same name lived in the town. Given the uniformity of early modern names, this is not a reliable method. The real percentage of Quaker litigators may have been lower. It is, however, safe to assume that some of the litigants he identified as Friends really were Quakers.

78 Historical Society of Pennslyvania (HSP) James Logan letter book 1717-1731: 28th 9ber 1719 to John Falconar; HSP James Logan letter book 1712-1715: 1st 7ber 1715 to John Askew; HSP Isaac Norris letter book vol. V: 29th 6 mo. 1710 to Rich. Champion. Several 'arbitration awards' are also extant. See, for example: HSP Clifford correspondence vol. 6, 1765, 106; HSP Clifford correspondence vol. 4, 164 - year unclear, after 1750; HSP Clifford correspondence vol. 5, 76 - year unclear, after 1750; HSP James Logan letter book 1712-1715: 1 7ber 1715 to John Askew; HSP Isaac Norris letter book vol. IV: 24th 2 mo. 1797 to Joseph Pyke in Bristol; HSP Isaac Norris letter book vol. V: 29th 6 mo. 1710 to Rich Champion; Ibid.: 1st 5th mo. 1712 to Wm Dale.

79 Philadelphia Yearly Meeting Discipline 1719, 28.

80 Ibid., 31.

81 Monthly Meeting of Friends in Philadelphia (MMFP), 1715-1744, 374, 6 mo 1744, George James vs Samuel Redman.

82 Ibid.

83 Ibid., 380, 7 mo 1744, George James vs Samuel Redman.

84 Ibid., 383, 10 mo 1744, George James vs Samuel Redman.

85 Examples for cases involving bills of exchange include: MMFP minutes 1682-1714, 39, 7 mo 1687, Samuel Carpenter vs Griffith Jones; Ibid., 61, 2 mo 1690, Richard Whitfield vs Richard Cubbon. Examples for cases involving difference in accounts include: MMFP minutes 1682-1714, 98, 12 mo 1695, Richard Davis vs David Powell; MMFP minutes 1715-1744, 300, 7 mo 1738, Benjamin Trotter vs Jacob Shute. Examples for cases involving debts upon bond include: MMFP minutes 1682-1714, 82, 4 mo 1693, Richard Dean vs Richard Sutton; Ibid., 311, 12 mo 1712, Widow Hallwell vs John Harper.

86 HSP Letter book of Francis Richardson.

87 MMFP Minutes 1715-1744, 92, 10 mo 1722, Richard Lundy vs Ebenezer Large et al.; MMFP Minutes 1682-1714, 104, 12 mo 1696, Ralph Jackson vs Josiah Ferne; Minutes 1682-1714, 39,7 mo 1687, Samuel Carpenter vs Griffith Jones; MMFP Minutes 1682-1714, 104, 12 mo 1696, David Powell and Richard Davis; MMFP Minutes 1682-1714, 281, 10 mo 1710, Griffith Owen vs John Martin's estate; MMFP Minutes 1715-1744, 251, 9 mo 1734, John Salkelds vs Martha Trueman; MMFP Minutes 1715-1744, 310, 11 mo 1738, Cadwallader Foulke vs Dennis Rochford; Minutes 1682-1714, 276, 6 mo 1710, John Rodman vs David Lloyd; MMFP Minutes 1682-1714, 322, 9 mo 1713, Widow Duckett vs Thomas Duckett; MMFP Minutes 1682-1714, 302, 4 mo 1712, Isaac Norris vs Mary Duckett; MMFP Minutes 1682-1714, 61, 2 
mo 1690, Richard Whitfield vs Richard Cubbon; MMFP Minutes 1682-1714, 171, 11 mo 1702, Widow Goldsmith vs Robert Haydock; MMFP Minutes 1682-1714, 39, 7 mo 1687, Samuel Carpenter vs Griffth Jones; MMFP Minutes 1682-1714, 117, 10 mo 1698, Nathanial Lamplugh vs Thomas Duckett; MMFP Minutes 1682-1714, 34, 2 mo 1687, Francis Richardson vs Elisabeth Frampton; MMFP Minutes 1682$1714,303,4$ mo 1712, Isaac Norris vs John Walker.

88 Gary B. Nash, 'The early merchants of Philadelphia: the formation and disintegration of a founding Elite', in Richard S. Dunn and Mary Maples Dunn eds., The World of William Penn (Philadelphia, 1986).

89 MMFP Marriages 1672-1759.

90 Clark et al. estimate the average adult population for this period by multiplying the total population estimates by 0.6 . 1,100 Philadelphia Friends in 1690 divided by $2 \Rightarrow>$ male population. Multiplied by 0.6 $\Rightarrow$ male adult population. See Gregory Clark, Joseph Cummins and Brock Smith, 'Malthus, wages, and preindustrial growth', The Journal of Economic History 72, 2 (2012), 15. For Philadelphia Quaker population estimate, see Marietta, The reformation of American Quakerism, 1748-1783, 47.

91 Robert Whitfield, Griffith Jones, Philip Howell, Robert Turner, Robert Howell, Joseph Willcox, James Fox.

92 Offutt, Of 'good laws' and 'good men', 96.

93 Charles Wilson Brooks, 'Pettyfoggers and vipers of the Commonwealth: the 'lower branch' of the legal profession in early modern England', in Cambridge studies in English legal history (1986), 69.

94 Craig Muldrew, The economy of obligation: the culture of credit and social relations in early modern England (Basingstoke, 1998); Craig Muldrew, 'Credit and the courts: debt litigation in a seventeenthcentury urban community', Economic History Review 43, 1 (1993), 24.

95 Simon Dixon, Quaker Communities in London, 1667-c.1714 (University of London, 2006), 42-3.

96 London Yearly Meeting, A Collection of the Epistles from the Yearly Meeting of Friends in London, To the Quarterly and Monthly Meetings in Great-Britain, Ireland and Elsewhere, from 1675 to 1820; Being from the First Establishment of that Meeting to the Present Time, New York, 1821, Epistle for 1725, 140.

97 Sahle, Esther. A faith of merchants: Quakers and institutional change in the early modern Atlantic, c. 1660-1800. Diss. The London School of Economics and Political Science (LSE), 2016.

98 MMFP, Minutes, 1690; See also Sahle, Faith of merchants.

99 Library of the Society of Friends, Minutes of London Monthly Meetings. In 1720, Philadelphia had one case, the five London monthly meetings between them 3, 1740 2:2, 1760 2:0. Numbers collected in author's previous work, reference omitted for anonymity.

100 Offutt, 'The limits of authority: courts, ethnicity, and gender in the middle colonies, 1670-1710', in Bruce H. Mann and Christopher Tomlins eds., The many legalities of early America (Chapel Hill, 2008), 364.

101 Marietta, The reformation of American Quakerism, 1748-1783; Richard Bauman, For the reputation of truth: politics, religion, and conflict among the Pennsylvania Quakers, 1750-1800 (Baltimore, 1971).

102 Conklin, 'Transformed, not transcended', 76; Phillips, 'Ancient and comely order', 95.

103 For studies of similar mechanisms, see Francesca Trivellato, 'Sephardic merchants in the early modern Atlantic and beyond. Towards a comparative historical approach to business corporation', in Richard L. Kagan and Philip D. Morgan eds., Atlantic Diasporas. Jews, Conversos, and Crypto-Jews in the age of mercantilism, 1500-1800 (2009), 108.

104 Marietta, The reformation of American Quakerism, 1748-1783.

105 Disownment as a punishment in arbitration cases recorded in Philadelphia Yearly Meeting, Book of Discipline, 1719, 34. Discussed by Conklin, 'Transformed, not transcended' and Phillips, 'Ancient and Comely Order', who however assume the nature of disownment to be harsher, and do not see the reputation angle of the threat.

106 11th month 1707, James Logan vs William Rakestraw, in MMFP Minutes 1682-1714, 241; 7th month 1721, Joseph Richardson vs Samuel and William Richardson, in MMFP Minutes 1715-1744, 77; 10th month 1722, Richard Lundy and Ebenzer Large vs Christopher Topham, in MMFP Minutes 1715-1744, 92; 1st month 1723, John Durborow and Edward Pleadwell vs executors of James Atkinson, in MMFP Minutes 1715-1744, 95; 4th month 1747, Thomas Nickson vs Adam Rhodes, in MMFP Minutes 17401755 (actually contains minutes 1745-1755), 38; 5th month 1746, Joseph Stretch vs Ralph Loftus, in MMFP Minutes 1740-1755 (1745-1755), 20; 1st month 1747, Isaac Norris and Elisabeth Norris vs executors of Nicholas Waln's estate, in MMFP Minutes 1740-1755 ( ... ), 33; 3rd month 1760, John Reynell/Elias Bland vs William Griffits, in MMFP Minutes 1757-1762, 240. 
107 10th mo 1739, Joshua Walton vs Hugh Durburrow, in MMFP Minutes 1715-1744, 313; 11th month 1753, Thomas Lightfoot vs Thomas Fisher, in MMFP Minutes 1740-1755 (1745-55), 282.

108 MMFP minutes 1682-1714, 89, begins 10 mo 1694, Patience Lloyd vs David Lloyd. Patience ends up going to law when not satisfied with the monthly meeting's verdict, not disowned; Ibid., 257, begins 1 mo 1709, James Kite vs Emmanuel Walker, Kite threatened with disownment twice, case continues, then disappears three months later. Ibid., 128, begins 10 mo 1699, Widow Langstone vs Daniel Pegg, Langstone receives two threats before the case disappears from minutes. Ibid., 219, begins 4 mo 1706, John Cadwallader on behalf of Gainer Owen vs Richard and Sarah Robinson, threat of disownment issued in second meeting, case continues for several months. Ibid., 290, beings 4 mo 1711, Arnold Cassel vs Caspar Hoodt et al., threat issued at third meeting, case continues for several months. MMFP minutes 1715-1744, 15, begins 11 mo 1715, Christopher Topham vs Robert Bonell, threat issued at first meeting, continues for two months. MMFP minutes 1740-1755 (actually contains minutes 1745-1755), 305, begins 6 mo 1754, Thomas Crosby vs Joshua Crosby, several months of threats, eventually disowned for a different matter.

109 Offutt, Of 'good laws' and 'good men', ch. 1.

110 Margo Todd makes this point for sixteenth and seventeenth centuries Scotland and England. Todd, 'For eschewing of trouble and exorbitant expense', 16.

111 Isaac Norris letter book vol. V, 351, 3rd 5 mo 1712, to Jane Duckett.

112 MMFP minutes 1715-1740, 28, 3 mo 1717.

113 Ibid., 32, 4 mo 1717.

114 Ended 5 mo 1717, 30. For similar cases, see, for instance: Fitzwater et al. vs Poole, 1714, 328. Cases that disappear after the threat include: MMFP minutes 1682-1714, 310, 11 mo 1712, John Jones vs Thomas Pryor; Ibid., 325, 10 mo 1713, Willia Reall vs Joshua Granger; Ibid., 323, 9 mo 1713, Richard Hill vs Samuel Taylor; Ibid., 323, 9 mo 1713, Thomas Barnes vs Thomas Broadgate; Ibid., 338, 9 mo 1714, Hugh Lowden vs Benjamin Farman.

115 John Smolenski, Friends and strangers: the making of a Creole culture in colonial Pennsylvania (2011), 131 .

116 Mary Beth Norton, 'Gender and defamation in seventeenth-century Maryland', The William and Mary Quarterly: A Magazine of Early American History and Culture (1987).

117 Norton, 'Gender and defamation in seventeenth-century Maryland', 14.

118 Smolenski, Friends and strangers, 131.

119 For examples of similar institutions and mechanisms outside the colonial American context, see Sebouh David Aslanian, From the Indian Ocean to the Mediterranean: the global trade networks of Armenian merchants from New Julfa (Berkeley, Calif. and London, 2011); Claudio Ferraz and Frederico Finan, 'Electoral accountability and corruption: evidence from the audits of local governments', The American Economic Review 101, 4 (2011); Benjamin A. Olken, 'Monitoring corruption: evidence from a field experiment in Indonesia', Journal of Political Economy, 2 (2007) on 21st century cases from Brazil and Indonesia.

120 Norton, 'Gender and defamation in seventeenth-century Maryland', 35.

121 Smolenski, Friends and strangers, 73; see also 75; John Smolenski, “'As the discharge of my conscience to god": narrative, personhood, and the construction of legal order in 17th-century Quaker culture', Prospects 24 (1999), 149.

122 Mann, 'The formalization of informal law'.

123 Todd, 'For eschewing of trouble and exorbitant expense', 15.

124 Galanter, 'Justice in many rooms', 13, 15.

125 Burset, 'Merchant courts, arbitration, and the politics of commercial litigation in the eighteenth-century British Empire' on Britain; Priest, 'Law and commerce, 1580-1815', 412 on the English north American colonies; Henry Horwitz and James Oldham, 'John Locke, Lord Mansfield, and arbitration during the eighteenth century', The Historical Journal 36, 1 (1993), 141 on England; On the colonies: Jones, 'An inquiry into the history of the adjudication of mercantile disputes in Great Britain and the United States'; Mann, 'The formalization of informal law' on widespread use of arbitration in seventeenth- and eighteenth-century Maryland; Oldham and Kim, 'Arbitration in America' on Scotland and England and London specifically in sixteenth and seventeenth centuries: Todd, 'For eschewing of trouble and exorbitant expense', 7-9.

126 MMFP Minutes 1682-1714, 1690, 2 mo, 61. See also Ibid., 11 mo 1702, 171, Widow Goldsmith vs Robert Haydock concerning debt in Hartshaw, Lacashire; Ibid., 6 mo 1710, 61, John Rodman and David Lloyd vs unnamed Friends in Flushing, New York. 
127 Ibid., 12 mo 1696, Ralph Jackson vs Josiah Ferne.

128 Isaac Norris letter book vol. V, 29th 2 mo 1713 to Geo Walker; Ibid., 24th 3 mo 17111 to John Knight; Ibid., 9th mo 1715 to Robert Haydock; Ibid., 24th Jan 1708/09 to Thomas Barker. Isaac Norris letter book vol. VI, 25 9ber 1717 to Joshua Taylor; Isaac Norris letter book vol. III, 30th 11 mo 1705/06 to Saml Chew Jr.; James Logan letter book 1717-1731, 28th 9ber 1719 to John Falconar.

129 MMFP Minutes 1682-1714, 115, 7 mo 1698, Thomas Fairman vs John Jones.

130 Letter book of Jonathan Dickinson 1698-1701, 295 mo 1698, to Dear Brother.

131 Nash, Quakers and politics, 61 on Samuel Carpenter; on Samuel Richardson, see Gary B. Nash, 'Up from the Bottom in Franklin's Philadelphia', Past and Present 1977, 1 (1977), 57.

132 MMFP Minutes 1682-1714, 36, 5 mo 1687, John Ithell vs Robert Turner.

133 Ibid., 37, 6 mo 1687, 6th month, John Ithell vs Robert Turner.

134 Offutt, Of 'good laws' and 'good men', 114 (49 per cent were recorded as agreed, ended, discontinued, or withdrawn before trial).

135 James Logan letter book vol. IV, 60, 25th 7ber 1717, to Henry Goldney and Silvanus Grove.

136 Sahle, Faith of merchants.

137 Marietta and Rowe, Troubled experiment, 56.

138 Ibid., 63-4.

139 Ibid., 157.

140 Clulow, The company and the Shogun; Stern, The company-state.

141 Ibid., 27.

142 Aslanian, Sebouh David. From the Indian Ocean to the Mediterranean: the global trade networks of Armenian merchants from New Julfa. Univ of California Press, 2014.

143 Zahedieh, 'Defying mercantilism'; Jessica Roitman, “'A flock of wolves instead of sheep”: the Dutch West India Company, conflict resolution, and the Jewish Community of Curacao in the eighteenth century', in Jane S. Gerber ed., The Jews in the Caribbean (Oxford, 2014); Hugo Martins, 'Justiça e litigação na comunidade judaico-portuguesa de Hamburgo, 1652-1682', Ler História 74 (2019). A 'Mahamad' also existed in the London Sephardi community, here however it only rarely dealt with commercial disputes. Alex Kerner, 'Arbitration and conflict resolution in the Spanish and Portuguese Jews' Congregation in London in the eighteenth century', Jewish Historical Studies 49, 6 (2018); Edgar Samuel, 'The Mahamad as an arbitration court', Jewish Historical Studies 41 (2007).

144 Zahedieh, 'Defying mercantilism', 78.

145 Cited in Zahedieh, 'Defying mercantilism', 78.

Note on manuscripts: All Philadelphia Quaker meeting records: Haverford Special Collections, Haverford College, Haverford, Pennsylvania. All London Quaker meeting records: Library of the Religious Society of Friends, London. All merchant correspondence: Historical Society of Pennsylvania, Philadelphia.

\section{French Abstract}

\section{Conformément à la loi et à l'Évangile. Résoudre les conflits commerciaux à Philadelphie en période coloniale}

Le commerce s'est beaucoup développé en océan Atlantique à l'époque moderne. Tout en reconnaissant que cette croissance a eu d'importantes conséquences économiques, sociales et culturelles, les chercheurs n'en ont pas encore pleinement élucidé les causes. Dans cet article, l'auteur soutient que les institutions religieuses qui avaient pignon sur rue jouèrent un rôle majeur dans ce processus. A partir des archives de Philadelphie datant de l'époque coloniale, il est montré comment les réunions de Quakers ont constitué un forum juridique à même de résoudre les conflits commerciaux. Leur Assemblée a fait valoir ses verdicts en recueillant et en diffusant nombre d'informations sur les différends intervenus, non seulement au niveau local mais aussi dans le monde atlantique, par le canal de la Société des Amis, l'organisation reconnue en charge des 
réunions. Ainsi se sont renforcés les mécanismes de réputation, facilitant l'expansion des activités commerciales de Philadelphie.

\section{German Abstract}

Recht und evangelische Ordnung: Die Lösung kommerzieller Streitfälle im kolonialen Philadelphia

Der Atlantikhandel hat in der Frühen Neuzeit in hohem Maße zugenommen, doch obwohl allgemein anerkannt wird, dass dieses Wachstum bedeutende ökonomische, soziale und kulturelle Konsequenzen hatte, gibt es noch immer keine vollständige Erklärung für die Ursachen. Dieser Beitrag geht davon aus, dass formalen religiösen Institutionen eine Schlüsselrolle zukam. Auf der Grundlage von Quellen aus dem kolonialen Philadelphia zeigt er, wie die Quäkergemeinde ein Rechtsforum für die Beilegung kommerzieller Konflikte schuf. Das Quaker Meeting setzte ihre Urteilssprüche durch, Indem es über die formale Organisation der Society of Friends Informationen über Konflikte sowohl vor Ort als auch über die atlantische Welt hinweg sammelte und verbreitete. Auf diese Weise wurden Reputationsmechanismen Verstärkt, die eine Ausdehnung von Philadelphias Handel erleichterten. 